\title{
LISENSI WAJIB PATEN SEBAGAI SALAH SATU WUJUD PEMBATASAN HAK EKSKLUSIF PATEN
}

\author{
Tony Hanoraga, Niken Prasetyawati
}

\begin{abstract}
Abstrak
Paten adalah hak khusus yang diberikan berdasarkan Undang-Undang oleh pemerintah kepada orang atau badan hukum yang mendapatkan suatu penemuan (invention) di bidang teknologi. Paten sebagai rezim kepemilikan dengan pemberian hak ekslusif (exclusive right) bukan bersifat tanpa batas. Negara boleh mengatur perkecualian secara terbatas hak eksklusif yang tercakup dalam paten. Asalkan perkecualian tersebut tidak secara tanpa alasan yang sah bertentangan dengan eksploitasi normal paten dan tidak merugikan kepentingan yang wajar dari Pemegang Paten, serta dengan tetap memperhitungkan kepentingan pihak ketiga. Salah satu wujud pembatasan hak eksklusif paten adalah aturan mengenai lisensi wajib (compulsory license).
\end{abstract}

Kata kunci : paten, hak eksklusif, lisensi wajib

Secara umum dalam Black's Law Dictionary, lisensi ini diartikan sebagai : A personal privilege to do some particular act or series of acts.... Dan The permission by competent authority to do an which, without such permission would be illegal, a trepass, a tort, or othewise would not allowable (Henry Campbell Black, 1996; 1279). Jadi berarti lisensi adalah suatu bentuk hak untuk melakukan satu atau serangkaian tindakan atau perbuatan yang diberikan oleh mereka yang berwenang dalam bentuk izin. Tanpa adanya izin tersebut, maka tindakan atau perbuatan tersebut merupakan suatu tindakan yang terlarang yang tidak sah yang merupakan perbuatan melawan hukum.

Jika kita coba telusuri lebih jauh maka lisensi yang didefinisikan dalam Black"s Law Dictionary, dimana dikatakan bahwa Licensing adalah :

The sale of a license permitting the use of patents, trademarks or the technology to another firm (Henry Campbell Black, 1996; 1280).

Dapat kita tarik kesimpulan bahwa makna lisensi secara tidak langsung sudah bergeser ke arah "penjualan" izin (privilege) untuk mempergunakan paten, hak atas merek (khususnya merek dagang) atau teknologi (diluar perlindungan paten = rahasia dagang) kepada pihak lain. Sampai sejauh inipun sesungguhnya lisensi jsh Jurnal Sosial Humaniora, Vol 8 No.2, Nopember 2015 
masih dikaitkan dengan kewenangan dalam bentuk privilege tersebut yang diberikan oleh negara untuk menggunakan dan memanfaatkan paten, rahasia dagang maupun teknologi tertentu. Dengan rumusan tersebut dapat kita tarik suatu kesimpulan bahwa lisensi merupakan hak privilege yang bersifat komersial dalam arti kata memberikan hak dan kewenangan untuk memanfaatkan paten maupun merek dagang atau teknologi yang dilindungi secara ekonomis.

Menurut Gunawan Widjaja lisensi merupakan suatu bentuk pemberian izin untuk memanfaatkan suatu hak atas kekayaan intelektual yang dapat diberikan oleh pemberi lisensi kepada penerima lisensi agar penerima dapat melakukan suatu bentuk kegiatan usaha, baik dalam bentuk teknologi atau pengetahuan (knowhow) yang dapat dipergunakan untuk memproduksi menghasilkan menjual atau memasarkan barang (berwujud) tertentu maupun yang akan dipergunakan untuk melaksanakan kegiatan jasa tertentu dengan mempergunakan Hak atas Kekayaan Intelektual yang dilisensikan tersebut (Gunawan Widjaj, 2001; 10-11). Untuk keperluan tersebut penerima lisensi diwajibkan untuk memberikan kontra prestasi dalam bentuk pembayaran royalty yang dikenal juga dengan license fee.

Sedangkan menurut Undang-Undang Paten Pasal 1 nomor 13,

Lisensi adalah izin yang diberikan oleh pemegang paten kepada pihak lain berdasarkan perjanjian pemberian hak unruk menikmati manfaat ekonomi dari suatu paten yang diberi perlindungan dalam jangka waktu dan syarat tertentu.

Sedangkan lisensi wijib di Indonesia diatur dalam Bab V Bagian Ketiga UndangUndang No 14 Tahun 2001 tentang Paten, dinyatakan bahwa:

Lisensi wajib adalah lisensi untuk melaksanakan paten yang diberikan berdasarkan keputusan Direktorat Jenderal atas dasar permohonan (pasal 74). 
Permohonan lisensi wajib hanya dapat dilakukan dengan alasan bahwa paten yang bersangkutan tidak dilaksanakan atau dilaksanakan tidak sepenuhnya di Indonesia oleh pemegang paten (pasal 75 ayat (2) UU No. 14 Tahun 2001). Permohonan lisensi wajib dapat pula diajukan setiap saat setelah paten atau penerima lisensi dalam bentuk dan dengan cara yang merugikan kepentingan masyarakat (pasal 75 ayat (3) UU No. 14 Tahun 2001). Lisensi wajib dapat pula sewaktu-waktu dimintakan oleh pemegang paten atas alasan bahwa pelaksanaan patennya tidak mungkin dapat dilakukan tanpa melanggar paten lain yang telah ada (pasal 82 ayat (1) UU No. 14 Tahun 2001).

Penerapan negara-negara dalam menyikapi dan menerapkan pelisensian wajib paten tidak seragam. Masing-masing bertolak dari latar belakang, pengalaman dan motivasi yang tidak selalu sama antara satu dengan yang lainnya. Negaranegara maju sudah banyak yang meninggalkan lisensi wajib dengan alasan sulitnya memberi justifikasi terhadap permintaan lisensi wajib, mengingat tidak adanya parameter guna mengukur ada atau tidaknya penyalahgunaan atau abuse, yang menjadi alasan bagi penerapan pelisensian wajib. Anggapan yang semakain berkembang di negara maju adalah, bahwa keberadaan konsep lisensi wajib semakin dianggap tidak populer, kerena tidak seiring dengan semangat dan tujuan pembangunan sistem HKI. Di negara berkembang seperti di Indonesia, Thailand, Brasil dan lainnya masih memberlakukan lisensi wajib pada undang-undangnya dengan berbagai alasan, seperti mengatasi penyalahgunaan hak, keseimbangan hak dan kewajiban, dan lainnya.

\section{Hak Kekayaan Intelektual Sebagai Sistem Kepemilikan}

Landasan Filosofi HKI dimulai sejak dikemukakannya ide penghargaan bagi pencipta atau penemu atas kreasi intelektual mereka yang berguna bagi masyarakat dalam politik Aristoteles pada masa abad keempat sebelum Masehi (Anthony D Amanto and Doris Estelle Long, 1996; 25).

Dalam berbagai diskusinya Aristoteles kerap sekali mengkritik secara tajam pendapat Hippodamus dari Miletus, yang mengajukan proposal Sistem Penghargaan 
(reward system) bagi mereka yang berjasa membuat penemuan yang berguna bagi masyarakat. Proposal 'menyatakan bahwa: "if you reward the creators of useful things, you get more useful things". Atas proposal ini, Aristoteles berpendapat bahwa : "A such system of individual reward may otherwise reduce social welfare .... A reward for revealing information to the state would give rise to fraudulent claims of discovery of malfeasance on the part of public officials" (Anthony D Amanto and Doris Estelle Long, 1996; 25).

Ada dua teori secara filosofi terkait anggapan hukum bahwa HKI adalah suatu system kepemilikan (property), teori tersebut dikemukakan John Locke dan Hegel. John Locke mengajarkan konsep kepemilikan (property) kaitannya dengan Hak Asasi Manusia (Human Righats) dengan pernyataannya: "Life, Liberty and Property" (Anthony D Amanto and Doris Estelle Long, 1996; 25). Locke menyatakan bahwa semula dalam status naturalis (state of nature) suasana aman tentram dan tidak ada hukum positif yang membagi kepemilikan atau pemberian wewenang seorang tertentu untuk memerintah orang lain. Hal ini merupakan kewajiban moral atas perilaku seseorang terhadap orang lain. Kewajiban mana di bebankan oleh Tuhan dan hal ini dapat di lihat dari berbagai alasan. Namun kemudian status naturalis tidak dapat terus di pertahankan karena Negara tersebut tidak memiliki hakim yang dapat memberikan terjemahan yang mengikat dari hukum alam untuk menyelesaikan pertentangan kepentingan antara individu. Untuk itu rakyat membentuk status civilis (state of civilized) karena kewenangannya akan menyediakan suatu pengaman bagi hak-hak alamiah yang tidak tersedia dalam status naturalis.

Baik konsepsi John Locke maupun Hegel berawal Teori Hukum Alam yang bersumber pada moralitas tentang apa yang baik dan apa yang buruk. Hak alamiah (natural rights) di derivasi dari alam yang sesungguhnya untuk materi yang berwujud. Keduanya tidak langsung memberikan konsepsi tentang Hak Kekayaan Intelektual (intellectual property rights). Artinya konsep umum dan pembenaran kekayaan telah di dominasi dari kekayaan yang berwujud (physical property). Pembenaran ontologi John Locke merujuk pada hak yang di asosiasikan dengan 
upaya seseorang (the Labour Theory), sedangkan Hegel merujuk pada hak yang diasosiasikan dengan kepribadian atau identitas diri (the personality theory).

John Locke menganggap bahwa barang-barang disediakan namun tidak dapat dinikmati dalam status naturalis sehingga seseorang harus mengkonversi barangbarang tersebut dari barang alamiah (natural good) menjadi barang pribadi (private goods) dengan melaksanakan upayanya terhadap barang-barang tersebut. Nilai tambah atas upaya pada barang-barang tersebut membuat barang-barang tersebut mampu dinikmati. Upaya yang telah dikorbankan seseorang inilah yang harus dihargai.

Hal yang sama ada pada HKI. Jika seseorang menciptakan atau menemukan sesuatu, maka seharusnya orang lain tidak merugikannya dengan melakukan penggandaan atau menyela atas proses kreativitas dan kegiatan menghasilkan penemuan tersebut karena pencipta, inventor atau pun pendesain kreasi intelektual memiliki kekayaan (property) atas kreasi intelektualnya.

Sebaliknya, Hegel lebih jelas dalam konsepsinya mengenai hak yang dimiliki manusia terpisah dari paham individualistis yang dikemukakan oleh Locke dan konsep Hegel menyempurnakan konsep Locke. Jika Locke menekankan pada upaya dalam menghasilkan kreasi intelektual merupakan hak yang harus di hargai dan secara langsung upaya berimplikasi pada kompensasi ekonomi (incentive) maka Hegel melengkapinya dengan penekanan kreasi intelektual merupakan perwujudan kepribadian (personality). Kepribadian sebagai abstrak (abstract right) merupakan alasan eksistensi manusia dan penghargaan tidak semata-mata kompensasi ekonomi tetapi lebih bersifat etis dan moral (reward) yang berimplikasi pada pengakuan hak moral (moral right).

Konsep Hegel menetapkan kapasitas hak seseorang bersama-sama dengan etika kehidupan dan perasaan Ketuhanan yang menetapkan standar moral minimum dan pada saat yang sama mencegah hal-hal yang tidak konsisten dari pernyataannya bahwa seseorang memiliki raganya secara alami dan itu bukan kekayaan (property). Hak abstrak (abstract right) bukan dari entitas manusia alamiah tetapi dari kehendak bebas di dalamnya dan dengan sendirinya, yang hal tersebut merupakan konsepsi 
abstrak. Kekayaan merupakan ekspresi dari kehendak sebagai bagian dari kepribadian dan hal itu menciptakan persyaratan untuk tindakan selanjutnya.

Perlindungan hukum sering bersifat terbatas dan bahwa penghargaan pada kekayaan intelektual di serahkan pada kekuatan hak tersebut serta penghargaan masyarakat yang tergantung pada kemampuan para pemikir dan toleransi masyarakat untuk mencegah peniruan. Menurut Hegel, kekayaan (property) sebagai identifikasi pribadi juga memberikan manfaat bagi masyarakat. Pangsa pasar adalah wasit melalui pasar individu mencoba meletakkan dan melindungi identitas diri melalui pertukaran kekayaan (property) secara sukarela yang mencerminkan kehendak individual. Masyarakat dalam hal ini memiliki keterbatasan hak untuk mencegah kepentingan individu yang wajar dalam pengakumulasian, penguasaan, pemberian izin atas kekayaan (property) nya. Kebutuhan masyarakat saja (as sunch) tidak akan membenarkan pengambil alihan kekayaan (property) seseorang tanpa adanya kompensasi yang layak.

Dengan demikian teori Hegel melengkapi teori Locke dengan dua alasan yakni (Spyros M. Maniatis, 2002; 5): Pertama, HKI adalah kekayaan (property) yang terkait dengan karya yang memperlihatkan kapasitas intelektual dan kreativitas manusia lebih dari pada sekedar konsumsi sebagaimana di kemukakan oleh Locke. Kedua, interpretasi Locke atas teori yang menunjukkan sekuens logika dari HKI bahwa manusia sejak awal memiliki raga dan upaya yang tunduk pada suatu 'padang pasir yang tidak bertuan' menjadi awal teori Hegel, bahwa HKI adalah merupakan hak abstrak yang menjadi alasan manusia eksis.

Sedangkan pengertian Hak (right) dalam Black's Law Dictionary diatikan :

as a noun and taken in an abstract sense, means justice, ethical correctness, or consonance with the rules of law or the principle of morals; a power privilege or immunity guaranted under constitution, statutes or decisional law or claimed as a result of long usage; A legally enforceable claim of one person againts another, that the other shall do a given act, or shall not do a given act ... Exclusive Right means right to exclude other for certain of time and take into account the limitation (Henry Campbell Black, 1996; 1216).

Hak adalah tuntutan yang dapat di tegakkan secara hukum dari seseorang terhadap pihak lain yang membuat pihak lain harus bertindak atau tidak bertindak (sesuai hukum yang berlaku). Hak eksklusif adalah hak untuk mengecualikan pihak 
lain dalam jangka waktu tertentu dengan memperhitungkan pembatasan yang berlaku. Soedikno Mertokusumo, menyatakan bahwa : "Hak adalah kepentingan yang dilindungi oleh hukum. Kepentingan adalah tuntutan perorangan atau kelompok yang di harapkan untuk di penuhi” (Sudikno Mertokusumo, 1989; 41).

Hak kebendaan yang memberikan kenikmatan yang sempurna bagi pemilik dinamakan "hak kepemilikan" yang di berbagai undang-undang negara dinamakan "property right". Kekayaan (property) diartikan sebagai :

that is perculiar or proper to any person that which belongs exclusively to one; In the strict legal sense, an aggregate of rights which are guaranted or protected by goverment; the word is also commonly used to denote everything which is the subject of ownership, corporeal or incorporeal, tangible or intangible visible or invisible real or personal everything that has an exchangeable value or which goes to make up wealth or estate (Mariam Darus Badrulzaman, 45)

Hak adalah sesuatu yang layak bagi setiap orang dan yang secara eksklusif dimiliki oleh seseorang. Kata ini juga secara umum digunakan untuk menunjukkan sesuatu yang tunduk pada kepemilikan baik yang jasmaniah maupun tidak, berwujud maupun tidak berwujud, terlihat maupun tidak terlihat, kekayaan atas benda berwujud maupun tidak, yang memiliki nilai yang dapat di pertukarkan atau dapat meningkatkan kekayaan atau kebendaan.

Konsep harta kekayaan menurut hukum Indonesia meliputi benda dan hubungan hukum untuk memperoleh benda tersebut. Dengan kata lain meliputi benda (zaak) dan perikatan (verbintenis) (Van Apeldoorn, 1973; 63-71). Harta kekayaan adalah benda milik seseorang yang memiliki nilai ekonomi (Abdul Kadir Muhammad, 1994; 10). Lebih lanjut menurut pasal 499 Burgelijke Wetboek (BW) pengertian benda (zaak) meliputi barang (good) dan hak (recht). Baik harta kekayaan maupun hak yang melekat diatasnya diakui dan dilindungi berdasarkan bukti yang sah. Sedangkan pengertian Hak Milik terdapat dalam pasal 570 BW yang menyatakan :

Hak kepemilikan adalah hak untuk menikmati kegunaan sesuatu kebendaan dengan leluasa dan untuk berbuat bebas terhadap kebendaan itu sepenuh- 
penuhnya asal tidak bertentangan dengan undang-undang atau peraturan umum yang di tetapkan oleh suatu kekuasaan yang berhak menetapkan dan tidak mengganggu hak-hak orang lain dengan tidak mengurangi kemungkinan akan pencabutan hak itu demi kepentingan umum berdasarkan atas ketentuan undang-undang dan dengan pembayaran ganti rugi.

Berdasarkan ketentuan tersebut maka hak atas barang milik hanya berlaku bagi barang bergerak meliputi :

1. hak menguasai dengan bebas;

2. hak menikmati dengan sepenuhnya;

3. secara tidak bertentangan dengan undang-undang (yang di perluas tidak bertentangan dengan hukum)

Pengertian hukum meliputi undang-undang, hukum tidak tertulis, kesusilaan dan ketertiban umum. Tidak bertentangan dengan hukum artinya sesuai dengan hukum atau dapat di benarkan dan di terima oleh pihak-pihak dalam masyarakat karena penggunaan hak milik secara wajar, layak dan patut. Keadilan, kelayakan dan kepatuhan adalah esensi hukum. Menurut Pitlo ada penyalahgunaan hak apabila penggunaan hak itu sedemikian rupa, sehingga kerugian orang lain lebih besar dari pada manfaat yang di peroleh pemilik yang menggunakan barang miliknya itu. Jadi, konsep kebebasan dalam hak milik yang tidak bertentangan dengan hukum, mengandung arti bahwa menguasai dan menikmati hak milik tidak boleh mengganggu orang lain atau menyalahgunakan hak yang merugikan orang lain (Abdul Kadir Muhammad, 1994; 38).

\section{Peran Negara Dalam Mewujudkan Persaingan Sehat}

Campur tangan Negara tidak lepas dari politik hukum suatu negara untuk mewujudkan tujuan negara. Tujuan negara Indonesia adalah : .... memajukan kesejahteraan umum .... yang tentunya harus dipahami secara arif sebagai suatu kebijakan yang mengacu sistem ekonomi pasar (market economic system).

Tujuan negara menurut $W$. Friedman. sebagai salah satu pemikir tentang negara kesejahteraan (welfare sate) bahwa negara hukum dalam fungsinya pada masyarakat nontotalitarian mengacu pada sistem ekonomi campuran (mixed economy system) yakni : "to indicate a situation in which the role of government as 
a owner and regulator has became sufficiently large to cast doubt on the validity of capitalist and free enterprise as appropiate adjective but not sufficiently large to justify the appellation socialist” (W. Friedmann, 1971; 1).

Sebaiknya Gunther Teubner (Gunther Teubner, 1986; 177) mengkritik konsepsi negara kesejahteraan (welfare state) bahwa negara dalam rangka mewujudkan kesejahteraan rakyat menghadapi dilema karena di satu sisi negara menggunakan instrumen publik (public instrument) dan di sisi lain hal ini justru membuat pemerintah sulit menghindarkan tindakan intervensi yang berlebihan dan bersifat kontraproduktif. Namun hal ini tidak berarti bahwa upaya peningkatan kesejahteraan menjadi terhenti karena kelemahan instrumen, metode atau pendekatan. Kesejahteraan harus di upayakan dalam rangka menegakkan keadilan suatu negara. Demikian halnya Richard A Slaughter, mengkritik konsep negara kesejahteraan sebagai konsep yang tidak sesuai dengan kondisi awal abad ke 21 yang merupakan perubahan life world dari pemenuhan kesejahteraan minimal menjadi pemenuhan kesejahteraan yang berkesinambungan (sustainable welfare) (Richard A. Slaughter, 2003; 24).

Sedangkan menurut Peter Mahmud konsep negara kesejahteraan (welfare state) terkesan regulatoris, tujuan negara untuk mewujudkan kesejahteraan rakyatnya dapat di capai melalui berbagai cara. Dengan demikian Tujuan negara dalam mewujudkan kesejahteraan rakyatnya tidaklah sama artinya dengan negara kesejahteraan (welfare state). Lebih lanjut menurut Peter Mahmud, Negara dalam upaya mensejahterakan rakyat dengan menciptakan kebijakan yang berorientasi pada sistem ekonomi pasar yang berciri :

1. Harus memberikan kemudahan (should be facilitative);

2. Harus tidak bersifat intervensi secara berlebihan (should be non interventionism);

3. Harus menciptakan aturan yang adil dan jujur (create fair and just rules).

Sistem ekonomi pasar dengan cirinya persaingan sehat (fair competition) merupakan tujuan agenda global WTO. Indonesia sebagai salah satu anggota WTO secara proaktif mendukung pencapaian persaingan sehat yang di yakini merupakan 
suatu persyaratan mutlak untuk menstimulasi kegiatan ekonomi, seperti yang di nyatakan oleh Stephen Sya Lieing Siew bahwa :

The best stimulant economic activity, according to the commission, is competition since it guarantees the widest possible freedom of action all. An active competition policy makes it easier the supply and demand structures to continually adjust to technological development if it is pursued in accordance with the provisions of the treaties establishing the communities. Competition enables enterprises to continuously improve their efficiency through the interplay of decentralized decision making machinery which is the sine qua non for steady improvement of living standards and employment prospects within the countries of the community. Competition policy is from this pint of view an essential means for satisfying the individual and collective needs of society to a great extent (Stephen Sya Lieing Siew, "Competition Policy in The EC, The Role of The Trety Provisions Relating to State Aids and Public Undertaking" Malaysian Law, http://www.clijlawcom.mem-bercentry/articles).

Persaingan sehat di percaya mampu menjadi penggerak kegiatan ekonomi karena hal tersebut menjamin kemungkinan kebebasan yang lebih luas dari tindakan bagi semua. Kebijakan persaingan yang aktif membuat lebih mudah struktur permintaan dan pasokan untuk menyesuaikan secara terus menerus perkembangan teknologi. Persaingan membuat perusahaan mampu secara terus menerus meningkatkan daya guna mereka melalui pengambilan keputusan yang terdesentralisasi yang juga menjadi sebab akibat peningkatan standar kehidupan dan prospek kepegawaian. Dalam sudut pandang ini, persaingan menjadi sarana untuk pemuasan kebutuhan individu dan kebutuhan bersama dari masyarakat secara luas.

Selanjutnya Paulo Bifany dalam United Nation Conference on Trade and Development United Nation Conference on Trade and Development (UNCTD) menyatakan bahwa :

Trade is no doubt that the protection of intellectual property become a crucial element of the trade policy of industrialized count to understand the phenomenon it is necessary first to exammine economic aspects involved and to link them with international and more specifically to the current structure and dynamics of international economic relations. 
Perlindungan HKI sebagai hak kepemilikan pribadi (private property) menjadi elemen yang krusial dari kebijakan perdagangan proses industri. Guna memahami gejala dan aspek ekonomi yang terkait dengan kebijakan perdaganan serta mengkaitkannya dengan struktur internasional atau secara khusus dinamika hubungan ekonomi internasional maka perlindungan HKI tidak dapat diabaikan.

Dalam skala perdagangan internasional telah terbentuk WTO yang merupakan hasil perjalanan panjang GATT melalui putaran perundingan (round). GAAT sendiri merupakan perjanjian multilateral (multilateral agreement) dan baru kemudian menjadi badan khusus (specialised agency) dari Perserikatan BangsaBangsa (United Nations). Perundingan GAAT dimulai pada Piagam Atlantik (Atlantic Charter) pada tahun 1941 yang pada saat itu setelah perang dunia II di sadari persyaratan terpenting untuk memelihara perdamaian dunia dengan menyusun perekonomian yang porak poranda (Philip Griffith, 1996; 2).

GAAT Putaran Uruguay tidak hanya berkenaan dengan tarif tetapi berlanjut pada negosiasi hambatan tarif memasukkan bidang jasa dalam agenda perundingan serta memasukkan TRIPs sebagai bidang yang memiliki pengaruh atas hambatan non tarif dan perdagangan jasa. Meski tidak dapat di pungkiri bahwa upaya memasukkan masalah HKI dalam agenda perundingan merupakan desakan Amerika, yang menginginkan adanya perjanjian yang menyediakan standar penegakan hukum HKI dalam arti memuat prosedur penyelesaian sengketa dan sanksi yang tegas apabila negara peserta tidak melaksanakan kewajibannya. Setelah melalui perundingan yang berjalan alot karena cukup banyak masalah akibat perbedaan yang sulit dipertemukan, Direktur Jenderal GATT dalam keduaukanya sebagai Trade Negotiating Committee mengambil prakarsa dan atas tanggung jawabnya sendiri merumuskan pasa-pasal TRIPs. Hal ini kemudian menyebabkan naskah (rancangan)TRIPs sebagai Chairman Text atau The Dunkel Draft.

TRIPs sebagaimana yang disebutkan dalam Annex 1C masuk secara koheren dan integral dengan persetujuan WTO. TRIPs memuat ketentuan sebagai berikut :

a. Part I General Provisions And Basic Principle (Article 1-8); 
b. Part II Standards Concerning the Availability Scope and Use of Intellectual Property Rights and Control of Anti Competitive Practice in Contractual Licences (Article 9-4);

c. Part III Enforcement of Intellectual Property (Article 41-61);

d. Part IV Acquistition and Maintenance of Intellectual Property Rights and Related "inter-partes" procedures (Article62);

e. Part V Dispute Prevention and settlement (Article 62-64);

f. Part VI Transitional Arrangements (Article 65-67);

g. Part VII Institutional Arrangement : Final Provisions (Article 68-73).

TRIPs memiliki tujuan umum dan fundamental yakni untuk mengurangi distorsi dan hal-hal yang menyulitkan kemajuan bagi perdagangan internasional (to reduce distortions and impediments to international trade). Tujuan TRIPs yang kedua adalah untuk melindungi hak-hak pribadi (to protect private property right). Negara anggota sepakat untuk memberdayakan pemegang HKI dan apabila pemegang HKI gagal menegakkan haknya maka pemerintah dapat diminta untuk membantu penegakan hukum ini melalui peraturan perundang-undangan dan kelembagaan hukum yang ada yang memungkinkan warga negara untuk melindungi dirinya sendiri melawan tindakan pelanggaran HKI - nya. Ketentuan ini melindungi pemegang HKI dari tindakan pelanggaran yang dilakukan pesaing, namun demikian dalam pembukaan (preamble), TRIPs juga menyatakan bahwa pemerintah tidak hanya ikut campur dalam kegagalan warga negara dalam menegakkan hak pribadinya namun TRIPs juga mempertimbangkan bahwa HKI yang tunduk pada hak kepemikikan pribadi yang berarti bahwa hak-hak tersebut tidak dapat diambil alih oleh pemerintah begitu saja tanpa kompensasi. Ketentuan ini merupakan jaminan hak pribadi warga negara untuk melindungi diri mereka dari kepentingan sah mereka dari tindakan pemerintah yang semena-mena, contohnya Article31(h0 yang menentukan apabila ada lisensi wajib maka pemegang paten khusus menerima kompensasi (remuneration) yang layak dalam situasi dan kondisi yang ada serta dengan memperhitungkan nilai ekonomi dari lisensi. Dengan kata lain TRIPs secara jelas melarang confiscation dari HKI kecuali pengurangan perlindungan tersebur 
sebagai konsekuensi dari konsekuensi dalam kerangka mekanisme penyelesaian sengketa.

Ketentuan dalam pembukaan (preamble) TRIPs lebih lanjut harus dikaitkan dengan Article 7 dan 8 TRIPs yang berguna untuk memberikan arah dan pedoman penginterpretasian TRIPs di masa depan. Article 7 TRIPs menetapkan bahwa perlindungan dan penegakan HKI harus mendukung penemuan teknologi untuk mengalihkan dan menyebarluaskan teknologi bagi kemanfaatan timbal balik antara produsen dan pengguna pengetahuan (teknologi) yang bersangkutan dalam suatu iklim yang kondusif bagi kesejahteraan sosial ekonomi masyarakat, serta kesinambungan hak dan kewajiban. Ketentuan ini bermaksud menjembatani kepentingan produsen teknologi dengan pengguna teknologi dalam skala lebih luas akan menciptakan harminisasi antara negara maju (developed countries). Selanjutnya Article 8 TRIPs menyatakan bahwa negara anggota dapat menetapkan atau mengubah hukum dan peraturan perundang-undangan mereka guna menetapkan ukuran perlindungan yang dibutuhkan bagi kesehatan masyarakat dan nutrisi dan untuk mendukung kepentingan umum dalam sektor vital yang penting untuk perkembangan sosio - ekonomi asalkan hal itu tidak bertentangan dengan TRIPs. TRIPs diharapkan menjadi dokumen yang bersifat dinamis, apa yang dibangun sekarang mungkin dapat berubah besok.

\section{Prinsip Umum Mengenai Paten}

Istilah "paten" yang dipakai sekarang dalam peraturan hukum di Indonesia adalah untuk menggantikan istilah octrooi yang berasal dari bahasa Belanda. Istilah oktroi ini berasal dari bahasa Latin dari kata auctorizare. Tetapi pada perkembangan selanjutnya dalam hukum kita istilah patenlah yang lebih memasyarakat. Istilah paten tersebut diserap dari bahasa Inggris yaitu "Patent". Di Perancis dan Belgia untuk menunjukkan pengertian yang sama dengan paten dipakai istilah "Brevet De Inventior".

Istilah paten bermula dari bahasa Latin dari kata auctor yang berarti di buka. Maksudnya adalah bahwa suatu penemuan yang mendapatkan paten menjadi terbuka untuk diketahui oleh umum (Muhamad Djumhana dan R. Djubaedillah, 
1997; 110). Dengan terbukanya tersebut tidak berarti setiap orang bisa mempraktekkan penemuan tersebut, hanya dengan izin dari si inventorlah suatu penemuan bisa didayagunakan oleh orang lain. Baru setelah habis masa perlindungan patennya maka penemuan tersebut menjadi milik umum pada saat inilah benar-benar terbuka.

Maksudnya diberikan paten ini, agar setiap penemuan dibuka untuk kepentingan umum guna kemanfaatan bagi masyarakat dan perkembangan teknologi. Dengan terbukanya suatu invensi yang baru maka memberi informasi yang diperlukan bagi pengembangan teknologi selanjutnya berdasarkan invensi tersebut dan untuk memberi petunjuk kepada meraka yang berminat dalam mengeksploitasi invensi itu.

WIPO memberi definisi paten sebagai berikut :

A patent is legally enforceable right granted by virtue of law to a person to exclude, for a limited time, others from certain acts in relation to describe new invention the privilege is granted by a goverment authority as a matter of rights to the person who is entitled to apply for it and who fulfils the prescribed condition (Philip Griffith, 1996; 15).

Dari pengertian diatas dapat kita lihat unsur penting dari paten, yaitu hak paten adalah hak yang diberikan oleh pemerintah dan bersifat eksklusif. Perbuatanperbuatan yang merupakan hak eksklusif dari si pemegang hak paten adalah produksi dari barang yang dipatenkan (manufacturing), penggunaan (using) dan penjualan (selling) dari barang tersebut dan lain-lain perbuatan yang berkaitan dengan penjualan barang itu seperti mengimpor dan menyimpan (stocking).

Dalam pemberian paten ini tidak semua invensi akan mendapatkannya, untuk mendapatkan paten suatu invensi harus memiliki syarat : substantif tertentu, yaitu kebaruan (novelty), bisa dipraktekkan dalam perindustrian (industrial applicability), mempunyai nilai langkah inventif (inventif step) dan juga memenuhi syarat formal (Abdul Kadir Muhammad, 2001; 1310).

Paten dalam pengertian hukum adalah hak khusus yang diberikan berdasarkan Undang-Undang oleh pemerintah kepada orang atau badan hukum yang mendapatkan suatu penemuan (invention) di bidang teknologi (Muhamad Djumhana 
dan R. Djubaedillah, 1997; 111). Berdasarkan hak tersebut maka si inventor untuk dalam jangka waktu tertentu dapat melaksanakan sendiri invensinya tersebut atau pun melarang orang lain menggunakan suatu cara mengerjakan atau membuat barang tersebut (method, process). Paten tersebut diberikan atas dasar permintaan.

Dari pengertian diatas dapat ditarik kesimpulan bahwa unsur yang terpenting dari paten adalah orang yang berhak memperoleh paten yaitu inventor atau yang menerima lebih lanjut hak inventor itu. Hak paten ada karena diminta oleh si inventor atau yang menerima lebih lanjut hak inventor. Penerimaan lebih lanjut hak inventor tersebut dapat terjadi karena pewarisan, hibah, wasiat, perjanjian tertulis atau sebab lain yang dibenarkan oleh UU (pasal 66 ayat (1) Undang-undang Paten No. 14 Tahun 2001). Yang dianggap inventor adalah seseorang yang secara sendiri atau beberapa orang yang secara bersama-sama melaksanakan ide yang dituangkan ke dalam kegiatan yang menghasilkan invensi.

Seperti halnya hak merek dan hak cipta, hak paten juga merupakan hak mutlak (absolute rechten) dapat berlaku terhadap setiap orang lain. Si pemegang hak paten (patentee) mempunyai hak-hak monopoli (exclussive right). Artinya dia dapat mempergunakan hak dengan melarang siapapun tanpa izinnya membuat apa yang telah dipatenkannya. Hanya saja pelarangan tersebut dibatasi ruang lingkupnya yaitu hanya meliputi perbuatan-perbuatan yang dilakukan untuk tujuan industri dan perdagangan serta dibatasi pula oleh jangka waktu tertentu. Terhadap pihak yang melakukan pelanggaran terhadap haknya dia dapat melakukan upaya hukum kepidanaan maupun keperdataan.

Hak paten merupakan benda dalarn arti kebendaan menurut Kitab Undangundang Hukum Perdata (jo Pasal 570 KUH Perdata), oleh karena itu merupakan sebagian kekayaan dari orang yang memilikinya. Hak paten tersebut merupakan benda bergerak yang dapat dipindahtangankan, misalnya dijual, dihibahkah, diwariskan dan sebagainya. Pemindahan hak itu dicatat di Direktorat Jenderal HKI, dan orang yang menerima pemindahan hak itu (assignee) menjadi pemilik baru paten itu.

Pemberian paten, sekalipun setelah melalui permeriksaan substansinya, tidak merupakan suatu jaminan hukum bagi paten itu bahwa patennya itu pasti sah 
menurut hukum. Keabsahan paten itu dapat digugat di depan pengadilan dalam suatu perkara pelanggaran paten. Suatu putusan pengadilan bahwa paten itu tidak sah, mengakibatkan paten itu tidak sah sejak pemberiannya. Sedangkan suatu putusan untuk membatalkan suatu paten mengakibatkan paten itu tidak sah sejak putusan tersebut.

\section{Pembatasan Hak Paten}

HKI sebagai rezim kepemilikan dengan pemberian Hak ekslusif (exclusive right) bukan bersifat tanpa batas. Article 30 TRIP menetapkan adanya perkecualian dari hak eksklusif Paten yakni :

Member may provide limited exception to the exclusive rights confered by a patent, provided that such exceptions do not unreasonably conflict with a normal exploitation of the patent and do not unreasonably prejudice the legitimate interests of the patent ownwr taking into account of the legitimate interests of third party.

Negara boleh mengatur perkecualian secara terbatas hak eksklusif yang tercakup dalam paten. Asalkan perkecualian tersebut tidak secara tanpa alasan yang sah bertentangan dengan eksploitasi normal paten dan tidak merugikan kepentingan yang wajar dari Pemegang Paten, serta dengan tetap memperhitungkan kepentingan pihak ketiga.

Salah satu wujud pembatasan hak eksklusif paten adalah aturan mengenai lisensi wajib (compulsory license). Lisensi wajib dalam hal ini dapat diberikan pada dua kategori pengguna yakni Pemerintah (atau badan Pemerintah atau pihak ketiga yang di beri kewenangan oleh negara) dan pihak ketiga pribadi lainnya. Perbedaannya didasarkan pada sifat alamiah lisensi dan bukan dari tujuan penggunaan. Sesungguhnya secara alamiah sangat tidak relevan menetapkan persyaratan untuk lisensi seperti jangka waktu dan royalti. Pemerintah dapat membebankan adanya lisensi wajib pada situasi dan kondisi yang khusus dengan perkecualian dan apabila ada alasan yang serius untuk membenarkan adanya lisensi 
wajib. Dalam kaitannya dengan ketentuan Article 7 TRIPs dan dengan memperhitungkan paragraph 4 preamble TRIPs, maka keseimbangan antara hak dan kewajiban tidak dapat di peroleh melalui pengurangan hak pemegang paten tanpa penambahan kepentingan kolektif masyarakat luas. Artinya hak individual dari pemegang paten tidak boleh dikurangi untuk kemanfaatan individu yang lain, hanya kepentingan sosial dan kolektiflah yang dapat membenarkan pembebanan lisensi wajib.

Persyaratan lisensi wajib pertama, Article 27 TRIPs secara implisit mengisyaratkan bahwa pemerintah tidak boleh membabankan lisensi wajib berdasarkan alasan kurangnya pekerjaan di wilayah setempat atau lokal. Oleh sebab itu pemegang paten dapat mengimpor produk yang di patenkan termasuk mengimpor produk yang di buat dengan proses yang telah dipatenkan. Kedua, lisensi wajib tidak boleh diberikan hanya karena alasan bahwa pemegang paten telah menolak memberikan lisensi pada pihak ketiga karena esensi dari hak eksklusif paten adalah memang untuk mengecualikan pihak ketiga yang tanpa seizinnya melaksanakan hak nya dan menggunakan invensinya. Mengingkari hak ini berarti merusak hak eksklusif paten tersebut dalam hal ini bertentangan dengan tujuan dari standar yang di tetapkan dalam TRIPs.

Jadi jika pemegang Paten tidak di berikan hak untuk menolak atau memberikan izin pihak lain melalui perjanjian lisensi maka kewajiban lisensi wajib tidak ada artinya. Justru aturan lisensi wajib ada karena penerima lisensi prospektif sebelumnya telah mencoba memperoleh lisensi secara sukarela (voluntary license), namun di tolak karena tidak sesuai dengan kehendak pemegang paten. Untuk itu pihak ketiga ini dapat meminta intervensi pemerintah untuk dapat di berikan lisensi wajib. Namun pihak ketiga ini harus berupaya untuk memperoleh lisensi sukarela dahulu, sebelum mengajukan lisensi wajib. Pihak ini juga harus pernah menawarkan persyaratan perjanjian yang layak dalam jangka waktu yang layak dan dengan manfaat komersial yang layak. Waktu yang layak yang di tetapkan Negara anggota lazim nya 90 hari atau 6 bulan bagi pemegang paten untuk menanggapi upaya pengajuan lisensi ini.

Alasan khusus lisensi wajib adalah : 
a.Untuk menetapkan hak setelah proses hukum atau administratif yang menetapkan adanya praktik yang bersifat antipersaingan (Article 31 (k));

b. Untuk mengizinkan pengeksploitasian paten yang tidak dapat di eksploitasi tanpa melanggar paten pihak lain (Article 31(1));

c.Untuk mencegah penyalahgunaan hak pemegang paten yang diakibatkan dari pelaksanaan hak eksklusif lainnya (Article 5A(2) dan (3) Paris Convention);

d. Untuk mengurangi ketiadaan atau tidak tercukupinya pelaksanaan invensi yang di patenkan(Article 5A(2) dan (3) Paris Convention);

e.Untuk kepentingan masyarakat antara lain sesuai dengan kebutuhan mendesak suatu negara atau situasi dan kondisi ekstrem lainnya atau kepentingan masyarakat yang tidak untuk penggunaan komersial (Article 31(b) TRIPs).

Negara anggota WTO tidak mengizinkan untuk menetapkan blanket license dalam ketentuan hukum nasional mereka. Oleh karena itu lisensi wajib tidak dapat diberikan secara otomatis dan ex officio untuk bidang teknologi tertentu.

Beberapa negara anggota menetapkan bahwa masalah kesehatan dan nutrisi merupakan area yang sejalan dengan kepentingan publik, sebenarnya tidak salah, namun menjadi masalah ketika dikaitkan dengan produk farmasi. Dalam Doha Declaration sebagai tindak lanjut TRIPs yang terkait dengan Akses Kesehatan pada tahun 2002 di tetapkan bahwa Negara anggota memiliki hak untuk menetapkan apa yang dianggap sebagai keadaan darurat (emergency) atau situasi dan kondisi lain yang bersifat amat mendesak (axtreme urgency). Hal yang dapat dianggap sebagai darurat nasional mencakup krisis kesehatan masyarakat termasuk di dalamnya HIV / AIDS, TBC, malaria dan penyakit menular (epidemic) lainnya. Dengan demikian jika semua masalah krisis kesehatan masyarakat membenarkan adanya lisensi wajib karena hal itu menyangkut kepentingan publik, namun sebaliknya tidak semua krisis kesehatan publik membenarkan pengecualian persyaratan Article 31(b) dari negosiasi lisensi sebelumnya. Dalam kasus penggunaan masyarakat untuk kepentingan yang bersifat non komersial, pemegang paten memiliki hak untuk di 
informasikan penggunaan oleh pemerintah atau pihak lain hanya jika keberadaan paten di ketahui tanpa adanya kebutuhan penelusuran paten.

Hukum nasional suatu negara dapat mensyaratkan agar intervensi yang telah diberikan paten wajib dilaksanakan di negara yang bersangkutan. Namun demikian pemegang paten harus diizinkan untuk di bebaskan dirinya dari kewajiban tersebut melalui importasi barang yang di patenkan (termasuk barang yang di hasilkan dengan proses yang di patenkan). Hal ini dapat dilihat dari ketentuan Article 31 TRIPS.

\section{Kesimpulan}

- HKI sebagai filosofis berasal dari konsepsi John Locke dan Hegel yang berawal dari Teori Hukum Alam, yang bersumber pada moralitas, tentang apa yang baik dan apa yang buruk. Berdasarkan pendekatan sejarah yang dilakukan, dapat dilihat bahwa pembenaran ontologi John Locke merujuk pada hak yang diasosiasikan dengan upaya seseorang (the Labour theory). Sedangkan Hegel merujuk pada hak yang diassosiasikan dengan kepribadian atau identitas diri (the personality theory). HKI sebagai aturan kekayaan (property) terkait dengan aturan kepemilikan (ownership) dan pelanggaran (tresspass). Pembenaran HKI sebgai kekayaan pribadi dikaitkan dengan adanya ketidaksetaraan (inequality) dalam masyarakat menyangkut pertanyaan kesetaraan penyebaran penguasaan (distributive equality) HKI. Untuk itu penyebaran penguasaan HKI sebagai sistem kekayaan dan sistem kepemilikan harus didasarkan pada prinsip keadilan (justice) secara substansial dan prinsip yang jujur dan fair (fairness) secara prosedural. Hal ini untuk mencegah kecenderungan tindakan penyalahgunaan HKI oleh pemegang HKI. Dalam hal ini dibutuhkan campur tangan negara untuk menata aturan yang ada. Saat ini secara multilateral telah dicapai kesepakatan internasional melalui Persetujuan Pembentukan WTO dengan salah satu agendanya TRIPs, yang berisi komitmen, konsesi dan negosiasi yang dibuat oleh para negara penandatangan, termasuk Indonesia untuk meningkatkan perlindungan HKI guna menciptakan persaingan sehat. 
HKI sebagai rezim kepemilikan dengan pemberian Hak ekslusif (exclusive right) bukan bersifat tanpa batas. Negara boleh mengatur perkecualian secara terbatas hak eksklusif yang tercakup dalam paten. Asalkan perkecualian tersebut tidak secara tanpa alasan yang sah bertentangan dengan eksploitasi normal paten dan tidak merugikan kepentingan yang wajar dari Pemegang Paten, serta dengan tetap memperhitungkan kepentingan pihak ketiga. Salah satu wujud pembatasan hak eksklusif paten adalah aturan mengenai lisensi wajib (compulsory license). Lisensi wajib dalam hal ini dapat diberikan pada dua kategori pengguna yakni Pemerintah (atau badan Pemerintah atau pihak ketiga yang di beri kewenangan oleh negara) dan pihak ketiga pribadi lainnya.

\section{DAFTAR PUSTAKA}

Amanto, Anthony D and Doris Estelle Long, International Intellectual Property Anthology, Anderson Publishing, Cincinnati, 1996.

Apeldoorn, Van, (trejemahan), Pengantar Ilmu Hukum, Pradnya Paramita, Jakarta, 1973.

Badrulzaman, Mariam Darus, Mencari Sistem Hukum Benda Nasional, BPHN, Jakarta.

Black, Henry Campbell, Black's Law Dictionary, St. Paul Minn, 1996.

Djumhana, Muhamad dan R. Djubaedillah, Hak Milik Intelektual Sejarah, Teori dan Prakteknya di Indonesia, Citra Aditya Bakti, Bandung, 1997.

Friedmann, W., The State and the Rule of Law in A Mixed Economy, Stevens \& Sons, London, 1971.

Gambiro, Ita, Hukum Paten, Sebelas Printing, Jakarta, tanpa tahun.

Maniatis, Spyros M., Trademark Rigghts - A Justification Based on Property, I.P.Q.: No. 2 Sweet and Maxwell, 2002.

Maulana, Insan Budi, Lisensi Paten, Citra Aditya Bakti, Bandung, 1996.

Mertokusumo, Sudikno, Mengenal Hukum, Liberty, Yogyakarta, 1989. 
Muhammad, Abdul Kadir, Hukum Ekonomi Hak Kekayaan Intelektual, Citra Aditya Bakti, Bandung, 2001.

Slaughter, Richard A., New Thinking for New Mellenium, 1996 dalam Sri Hajati, Hak atas Tanah dalam Kaitannya dengan Investasi, Disertasi, Program Studi Ilmu Hukum Program Doktor Program Pascasarjana, Universitas Surabaya, Surabaya, 2003

Teubner, Gunther, Dilemmas of Law in The Welfare State, Walter, New York, 1986.

Widjaja, Gunawan, Lisensi, Raja Grafindo Persada, Jakarta, 2001.

Griffith, Philip, Harmonstion of Patent Laws-the WIPO Long Term Goal, Makalah, disampaikan dalam Pelatihan Pengajar Hukum Hak Atas Kekayaan Intelektual, Surabaya, 10-25 September 1996.

Siew, Stephen Sya Lieing, "Competition Policy in The EC, The Role of The Trety Provisions Relating to State Aids and Public Undertaking” Malaysian Law, http://www.clijlaw-com.mem-bercentry/articles.

Jened, Rahmi, Implikasi Persetujuan TRIPs terhadap Perlindungan Merek Di Indonesia, Majalah Yuridika, Fakultas Hukum Universitas Airlangga, Surabaya, 2000. 